Research article

\title{
DIAGNOSIS OF Q FEVER AND BRUCELLOSIS IN ABORTED OVINE FETUSES BY MICROBIOLOGICAL, PATHOLOGICAL AND IMMUNOHISTOCHEMICAL METHODS
}

\author{
YESILMEN Simten ${ }^{1}$, YAMAN Turan² ${ }^{2 *}$ SAĞSÖZ Hakan ${ }^{3}$, BADEMKIRAN Servet ${ }^{4}$ \\ ${ }^{1}$ Department of Microbiology, Faculty of Veterinary Medicine, University of Dicle, Diyarbakir, Turkey; \\ ${ }^{2}$ Department of Pathology, Faculty of Veterinary Medicine, University of Van Yuzuncu Yil, Van, \\ Turkey; ${ }^{3}$ Department of Histology and Embryology, Faculty of Veterinary Medicine, University of \\ Dicle, Diyarbakir, Turkey; ${ }^{4}$ Department of Obstetric and Reproduction, Faculty of Veterinary Medicine, \\ Diyarbakir, Turkey
}

(Received 24 December 2017, Accepted 11. June 2018)

\begin{abstract}
Brucellosis and Q fever, two zoonoses, are important causes of abortion in ruminants, as well as economically significant diseases caused by a gram-negative bacterium. Determination of these diseases is therefore of great importance. In this study, the organs of 35 naturally infected and aborted ovine fetuses were examined for the presence of changes resulting from infections by Brucella melitensis and Coxiella burnetii, according to macroscopic, bacteriological, histopathological and immunohistochemical methods. B. melitensis was observed in 21 cases, and C. burnetii was observed in 8 cases of the aborted ovine fetuses, and these were determined with immunohistochemical methods. Brucellosis was observed in 18 of the aborted ovine fetuses, and this was determined by microbiological methods. Negative (-) results were found for all of the other fetuses. The Brucella antigen was determined to be localized as intracytoplasmic in mainly alveolar macrophages, bronchi, bronchioles, glandular epithelial cells around bronchial glands, neutrophils, hepatocytes and Kupffer cells. The Coxiella antigen was found to be localized in the alveolar macrophages in the lungs, bronchi, bronchioles and alveolus, and in the cytoplasms of bronchial gland epithelial cells, and in the cytoplasms of hepatocytes and Kupffer cells in the liver. Immunohistochemical and microbiological diagnoses of brucellosis and coxiellosis were compared; it was concluded that immunohistochemical methods were more safely applied than microbiological methods.
\end{abstract}

Key words: Q fever, Brucella melitensis, immunohistochemistry, abortus.

\section{INTRODUCTION}

One of the factors having a negative impact on raising livestock globally is animal abortions (1). Since the clinical findings of bacterial diseases causing abortions in sheep are atypical, the laboratory diagnosis of these diseases gains significance. In the necropsies of aborted fetuses, macroscopic findings such as a serohemorrhagic

*Corresponding author: e-mail: turanyaman@yyu.edu.tr 
exudates in body cavities, necrotic foci in the liver, diffuse subcutaneous edema, yellow turbid content of the abomasum and color changes in the lungs ranging from grey to red as well as histopathologically confirmed varying degrees of catarrhal pneumonia, necrosis in the liver and hepatitis are also reported in sheep abortions caused by diseases such as coxiellosis, campylobacteriosis, listeriosis and chlamydiosis. In this sense, the pathologic diagnoses of aborted fetuses should include the isolation of the causative agent, as well as immunohistochemical studies [1-4].

Since brucellosis and $\mathrm{Q}$ fever are zoonotic diseases, they comprise a high-level biologic risk for laboratory staff who are isolating and identifying causative agents [1,5]. The isolation of C. burnetii must be done only in biosafety level 3 laboratories and experienced personnel should be allowed to manipulate contaminated specimens and cultivate these agents [5]. Therefore, immunohistochemical studies of fixed tissues taken from aborted lambs and afterbirths have taken priority in the diagnoses $[1,5,6]$.

The present study focused on cases of brucellosis and coxiellosis with the goal of determining the severity and distribution of the lesions in fetal tissues and localization of the causative agents in the cells in the pathogenesis of the disease by using histopathological, immunohistochemical and microbiological methods. In addition, the reliability of microbiological and immunohistochemical methods for the detection of these agents were compared.

\section{MATERIALS AND METHODS}

\section{Animals and samples}

The samples were collected from Diyarbakir and surrounding cities in Turkey. The materials used in this study comprised 35 aborted fetuses brought to the University of Dicle, Faculty of Veterinary Medicine, Department of Microbiology, between October 2012 and February 2013. Tissue samples taken from the liver and lungs of the aborted fetuses were preserved in sterile sample containers for microbiological and pathological examination. Tissue samples were embedded in paraffin following the routine pathological procedure using a buffered formalin solution of $10 \%$ and cutting two sections of $5 \mu \mathrm{m}$ thick paraffin blocks. One of the sections was used for the immunohistochemistry stage and mounted on an adhesive slide, whereas the second section was stained with haematoxylin-eosin and examined with a light microscope.

\section{Bacteriological examination}

The specimens from fetal organs were cultured on Brucella medium Brucella Medium (Oxoid, CM 169) and supplemented with Brucella Selective Supplement (Oxoid, SR209E). Cultures were incubated at $37^{\circ} \mathrm{C}$ for 5 to 7 days aerobically and microaerobically (Microaerobic Kit, Merck, Anaerocult C). Suspected Brucella colonies were identified on the basis of Gram stained morphology, cultural characteristics, motility, production of catalase, urease, oxidase and $\mathrm{H} 2 \mathrm{~S}$, and growth in the presence 
of CO2. Confirmations of all isolates were made by the VITEK 2 automated system on GN cards. The results showed that 18 cases had B. melitensis, which was isolated from the lungs and liver in 7 cases, from the lungs in 9 cases and from the liver in 2 cases. Identification with the VITEK 2 system confirmed that all suspicious colonies were those of B. melitensis [7-9].

\section{Immunohistochemistry (IHC) staining}

The streptavidin-peroxidase method (ABC) was used to stain the sections. After deparaffinizing and rehydrating, the sections were rinsed in distilled water. After quenching endogenous peroxidase activity with $3 \% \mathrm{H}_{2} \mathrm{O}_{2}(\mathrm{v} / \mathrm{v})$ for 20 min, the slides were washed twice in $0.01 \mathrm{M}$ PBS for $5 \mathrm{~min}$. Before adding the primary antibodies, the slides were incubated with blocking serum (Histostain Plus Bulk Kit, Zymed, South San Francisco, CA, USA) for 15 min to block nonspecific binding without performing antigen retrieval. The sections were incubated with B. abortus (Becton Dickinson and Company, Cat No: 240934) polyclonal antibody and anti-C. burnetii hyperimmune serum, overnight at $4^{\circ} \mathrm{C}$, diluted 1:200. After incubation, the slides were washed four times in $0.01 \mathrm{M}$ PBS for $5 \mathrm{~min}$, incubated with biotinylated secondary antibody (Histostain Plus Bulk Kit, Zymed) for $20 \mathrm{~min}$ at room temperature, then washed four times in $0.01 \mathrm{M}$ PBS for $5 \mathrm{~min}$. After incubation with the secondary antibody, the sections were incubated with streptavidin-peroxidase (HRP) conjugate (Histostain Plus Bulk Kit, Zymed) for $20 \mathrm{~min}$, then washed four times in $0.01 \mathrm{M}$ PBS for $5 \mathrm{~min}$ following the enzymatic incubation. To visualize the reactions, the sections were reacted for 5-15 min with diaminobenzidine (DAB) for B. abortus and C. brunetti staining. After the development of the DAB reactions, the sections were counterstained with Gill's haematoxylin. The sections then were passed through alcohol and xylene and mounted directly with Entellan mounting medium. Negative controls were used to verify staining. The slides were reacted with PBS instead of primer antibodies as negative controls. The slides were examined and photographed using a light microscope (E-400; Nikon, Tokyo, Japan) equipped with a DS-RI1 video camera (DS-U3, Nikon, Tokyo, Japan).

The histopathological findings under a light microscope (E-400; Nikon, Tokyo, Japan) were evaluated semi quantitatively according to the severity of the lesions as $(-)$ no lesion, $(+)$ mild, $(++)$ moderate and $(+++)$ severe. Likewise, the immunohistochemical findings were evaluated according to the intensity of staining in the tissue as (-) negative, $(+)$ mild, $(++)$ moderate and $(+++)$ intense.

\section{RESULTS}

\section{Gross lesions}

The macroscopic findings were similar in aborted fetuses infected by Brucella. These fetuses had edema in the subcutaneous tissue. There was a light-red colored serous fluid in their abdominal cavities. In most of the aborted fetuses, the liver was found 
to have grown slightly and its edges were massless. The lungs showed pneumonia and pleuritis. The lung lobes were hardened, and there were fibrin filaments in the thorax and on the lungs. In cases with fibrin formation, a small quantity of light-colored serous fluid was observed in the thorax. In other cases, an accumulation of light-red serous fluid was present in the thoracic cavity. The abomasum content was of dense consistency and yellowish and contained particles (Figures 1A and B). There were no macroscopic findings in aborted fetuses infected by C. burnetii.

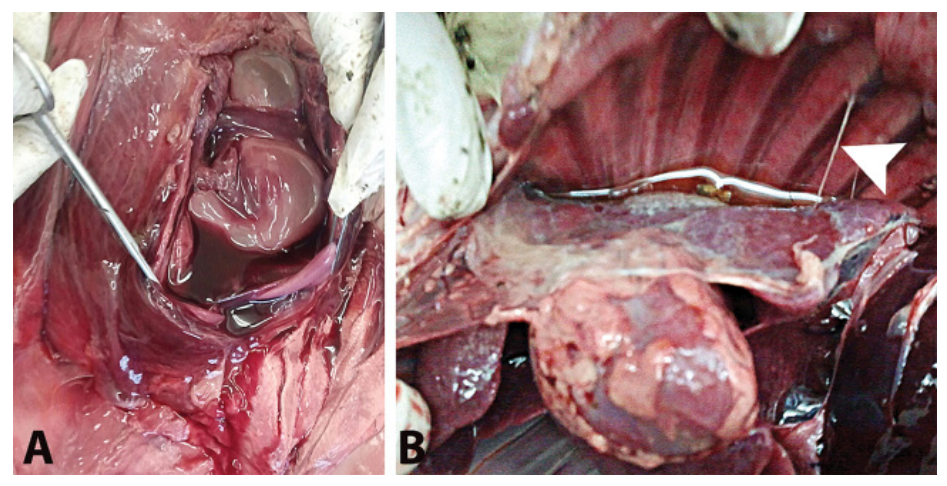

Figure 1. Haemorrhagic and serous fluid in abdominal cavity (A) and fibrinous pleuropneumonia (B) in aborted fetus.

\section{Histopathology}

In fetuses infected by B. melitensis, the most widely seen histopathologic changes were in the lungs and liver. Bronchopneumonia was determined in 10 cases, and interstitial pneumonia in 8 cases. The inflammatory cell infiltrations, which consisted of macrophages, lymphocytes and neutrophils, were observed mainly within alveoles and bronchiole lumens. The exudate in bronchioles and alveoles consisted of moderate or

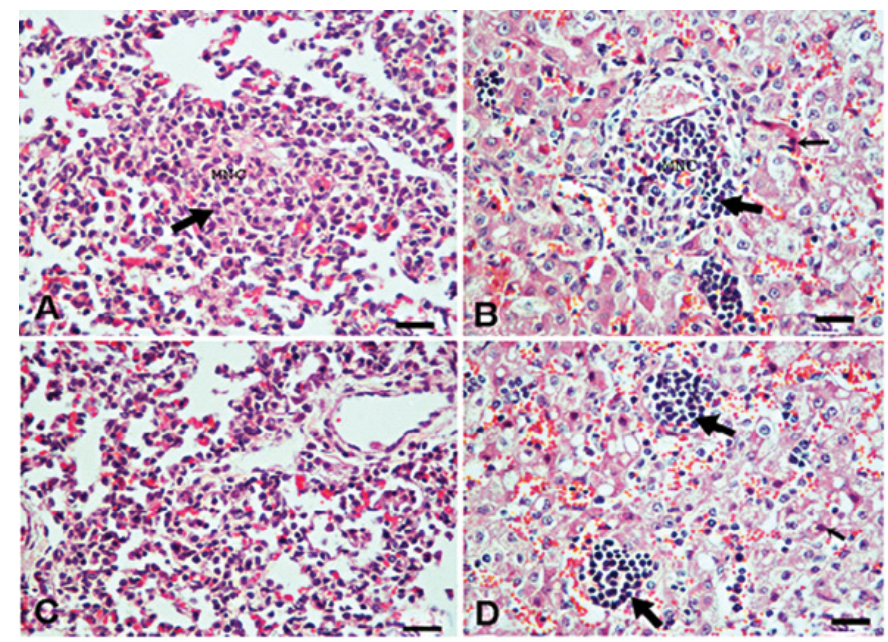

Figure 2. Microscopical changes in fetal lung and liver with Brucellosis $(\mathbf{A}, \mathbf{B})$ and $C$. burnetti $(\mathbf{C , D})(\mathrm{H} \& \mathrm{E}, \mathrm{Bar}=25 \mu \mathrm{m})$. 
high amounts of fibrin, cellular debris, neutrophils and macrophages. In fetuses with interstitial pneumonia, interalveolar septa were thickened as a result of hyperaemia and lymphoid cell infiltration (Figure 2A). The most frequent changes in the liver were mononuclear and polymorphonuclear cell infiltrations. Degeneration and necrosis of hepatocytes were present (Figure 2B).

In fetuses infected with $C$. burnetii, interstitial pneumonia was observed. Interalveolar septa were thickened by inflammatory cell infiltration. There were intrasinusoidal mononuclear cell foci in the liver. Additionally, there were infiltrations by neutrophil leucocytes in the liver parenchyma. Also, degeneration and necrosis were observed in some hepatocytes (Figures 2C and D).

\section{Immunohistochemistry}

Among the 35 fetuses studied, immunohistochemical reactions for B. melitensis were lung-positive in 18 cases (51\%) and liver-positive in 14 cases (40\%); and for C. burnetii, lung-positive in 3 cases $(2.86 \%)$ and liver-positive in 4 cases $(11.43 \%)$.

B. melitensis antigen was detected as intracytoplasmic granules within alveolar macrophages in the lungs. The causative agents were localized particularly in the apical cytoplasm of glandular epithelial cells around the bronchi and bronchioles. Moreover, the bacterial antigens were localized in the cytoplasm of the cells (most likely, neutrophils and macrophages) found in the lumen of bronchi, bronchioles and blood vessels. Intracytoplasmic Brucella antigens were observed in the hepatocytes and Kupffer cells in the liver (Figure 3A). No immunoreaction was detected in the cells of plaques formed by inflammatory lymphocyte infiltrations in both the liver and lungs.

It was observed that in the lungs, the Coxiella antigen was localized particularly within the apical cytoplasm of gland epithelial cells, bronchi, bronchioles, alveoles and alveolar macrophages. In the liver, the antigen was localized in the cytoplasm of hepatocytes and Kupffer cells, and the cell nuclei were generally covered with the antigenic reaction (Figure 3B). Also, the free antigen was found in the sinusoids. There was no reaction in choleduct epithelium.

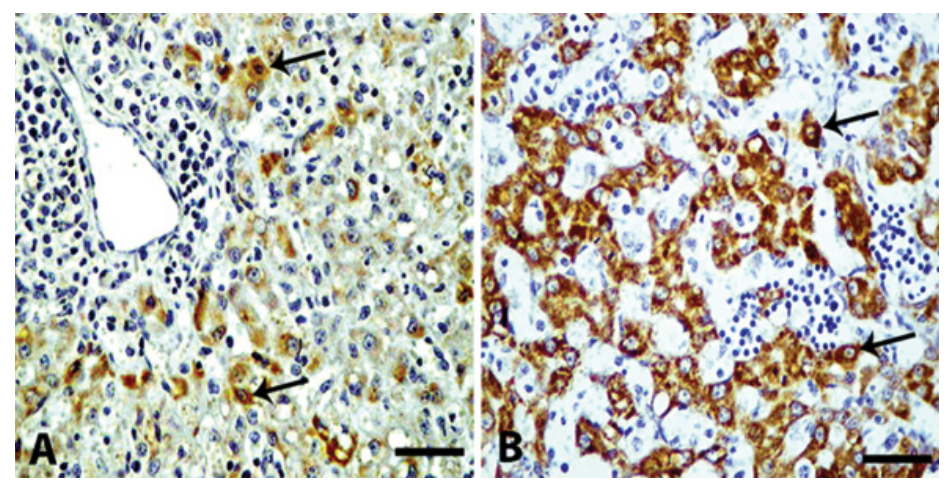

Figure 3. Expression of Brucella spp. antigens (A) and C.burnetti antigens in liver (B) (IHC, Bar $=25 \mu \mathrm{m})$. 


\section{Bacteriological examination}

Specimens from the fetal organs were inoculated onto enriched Brucella medium, and the bacteria in grown suspicious colonies were identified with the VITEK 2 automated system. The results showed that 18 cases had B. melitensis, which was isolated from the lungs and liver in 7 cases, from the lungs in 9 cases and from the liver in 2 cases. Identification with the VITEK 2 system confirmed that all suspicious colonies were those of B. melitensis.

Immunohistochemical and culture results obtained from the lungs and liver of $B$. melitensis and C. burnetii infected fetuses are summarized in Table 1.

Table 1. Immunohistochemical and culture results obtained from lung and liver of B. Melitensis and C. Burnetii infected fetuses are summarized

\begin{tabular}{|c|c|c|c|c|}
\hline \multirow{2}{*}{$\begin{array}{l}\text { Foetus } \\
\text { No. }\end{array}$} & \multirow{2}{*}{$\begin{array}{l}\text { Brucella } \\
\text { culture }\end{array}$} & \multicolumn{2}{|c|}{ İmmunohistochemistry* } & \multirow[b]{2}{*}{ Lung lesions } \\
\hline & & Liver & Lung & \\
\hline 1 & + & - & ++ & $\mathrm{BP}$ \\
\hline 2 & - & + & +++ & $\mathrm{BP}$ \\
\hline 3 & + & ++ & +++ & $\mathrm{BP}$ \\
\hline 4 & + & - & ++ & IP \\
\hline 5 & + & - & ++ & IP \\
\hline 6 & + & + & - & 0 \\
\hline 7 & + & - & ++ & IP \\
\hline 8 & - & + & - & 0 \\
\hline 9 & + & + & + & IP \\
\hline 10 & + & ++ & ++ & $\mathrm{BP}$ \\
\hline 11 & + & + & + & IP \\
\hline 12 & + & + & ++ & $\mathrm{BP}$ \\
\hline 13 & + & + & ++ & IP \\
\hline 14 & + & + & - & 0 \\
\hline 15 & + & ++ & +++ & $\mathrm{BP}$ \\
\hline 16 & + & ++ & +++ & $\mathrm{BP}$ \\
\hline 17 & + & - & ++ & $\mathrm{BP}$ \\
\hline 18 & + & - & ++ & IP \\
\hline 19 & - & + & +++ & $\mathrm{BP}$ \\
\hline 20 & + & ++ & ++ & $\mathrm{BP}$ \\
\hline 21 & + & - & + & IP \\
\hline Foetus No. & C. Burnetii culture & & & \\
\hline 1 & No made & + & ++ & IP \\
\hline 2 & No made & + & - & 0 \\
\hline 3 & No made & + & ++ & IP \\
\hline 4 & No made & ++ & +++ & IP \\
\hline 5 & No made & - & + & IP \\
\hline 6 & No made & - & + & IP \\
\hline 7 & No made & + & - & 0 \\
\hline 8 & No made & + & - & 0 \\
\hline
\end{tabular}

*Amount of antigen: - : negative; + : low; ++ : moderate; +++ : abundant. BP: Bronchopneumonia; IP: Interstitial pneumonia; 0: No lesions observed 


\section{DISCUSSION}

Bacteriological isolation, histopathologic and immunohistochemical methods are frequently used in the laboratory diagnosis of Brucella and Coxiella infections. The Brucella and Coxiella antigens can be correctly identified in fixed tissues by using immunohistochemical techniques. The isolation of the causative agents from blood and tissues are also required for the diagnosis of brucellosis and coxiellosis, but isolation may be unsuccessful with severely autolyzed tissues. Determination of specific antibodies in the serum provides an indefinitive diagnosis. Antibody levels rise in acute infections, but in chronic infections they are insignificant. Also, due to frequently occurring cross-reactions, serologic tests may yield false-negative results. Consequently, in cases of infected abortus, the determination of Brucella and Coxiella antigens with the highly sensitive and specific immunohistochemical methods is preferred [10-15].

In this study, the lesions in the aborted fetuses of sheep infected with B. melitensis were morphologically evaluated. Relevant studies have reported that fetuses with brucellosis are edematous and have a light-red colored fluid accumulation in their thoracic and abdominal cavities [16]. They also show other pathologic changes, such as pneumonia [16], pleuritis with fibrin formation and abnormal abomasum content $[17,18]$. The macroscopic findings of the present study were consistent with the findings of the mentioned studies.

Pneumonia is the most often seen and diagnosed lesion in Brucella infections [3,4]. Bronchopneumonia and interstitial pneumonia are characteristic lesions in fetuses with brucellosis [17]. The main finding in the present study was histopathologically confirmed pneumonia in 18 cases out of 21 cases. In fetal lungs with bronchopneumonia, cellular debris, macrophages and neutrophils were observed in the lumens of alveoles, bronchi and bronchioles. In fetal lungs with interstitial pneumonia, interalveolar septa were thickened by mononuclear cell infiltration and hyperaemia. Hepatitis is another pathology found in animal brucellosis [19]. Experimental studies on infected sheep [20] and goat [3] fetuses have shown the presence of a periportal cell infiltration in the liver. Likewise, the present study showed periportal and sinusoidal mononuclear leukocyte infiltration, as well as degenerative and necrotic hepatocytes in the liver. Our findings are similar to the findings reported by Milli (2001) [16].

In the present study, among the 35 fetuses examined, immunohistochemical reactions for B. melitensis were lung-positive in 18 cases (51\%) and liver-positive in 14 cases $(40 \%)$. Compatible with other studies $[1,4,18]$, the present study showed that in the lungs, Brucella antigens were localized intracellularly in macrophages and neutrophils and extracellularly in the cellular debris in the lumen of bronchi, bronchioles and alveoles and in the bronchiole epithelium; and in the liver, intracellularly in hepatocytes, Kupffer cells, macrophages and neutrophils.

Studies have reported that there is no macroscopical finding in aborted fetuses infected with C. burnetii [21-23]. Also in the present study, no morphological changes 
were observed in aborted fetuses with $C$. burnetii infection. It has been reported that in C. burnetii-induced abortions, the histopathological lesions in the fetuses are generally mild with insignificant or inconsistent microscopic features [21,24] and significant lesions are found in the placenta [22,24]. Compatible with these findings, the lesions detected in our study were mild. We found interstitial lymphocyte and mononuclear cell infiltrations foci [11,14] and necrosis of hepatocytes in the liver [25] and a mild interstitial pneumonia in the lungs [24,25].

It has been reported that positive immunohistochemical results are obtained in cow abortus caused by $C$. burnetii [26]. C. burnetii is localized within the macrophages in lung alveoles in infected goats [13]. In the present study, among the 35 sheep fetuses examined, C. burnetii was immunohistochemically shown in the lungs of 3 cases $(2.86 \%)$ and in the liver of 4 cases (11.43\%). In the lungs, Coxiella antigens were found localized intracellularly in alveolar macrophages and in the glandular epithelial cells of bronchi, bronchioles and alveoles. In the liver, the antigen was localized in the cytoplasm of hepatocytes and Kupffer cells, and the cell nuclei were generally covered with the antigenic reaction. Also, the free antigen was found in the sinusoids.

It is concluded that in suspicious cases in which bacteriological examination is impossible or negative, or when specimens are already fixed in formalin, the causative agents Brucella and Coxiella can be detected with the immunohistochemical technique, which is a reliable method for diagnosing brucellosis and coxiellosis.

\section{Acknowledgements}

We thank Prof. Zabit Yener for valuable comments on the manuscript.

\section{Authors' contributions}

SY drafted the manuscript and did the microbiological cultivation. TY drafted the manuscript and participated in the necropsies and histopathological analyses. HS carried out immunohistochemical staining. SB helped to draft the manuscript. All authors read and approved the final manuscript.

\section{Declaration of conflicting interests}

The author(s) declared no potential conflicts of interest with respect to the research, authorship, and/or publication of this article.

\section{REFERENCES}

1. Ilhan F, Yener Z: Immunohistochemical detection of Brucella melitensis antigens in cases of naturally occurring abortions in sheep. J Vet Diagn Invest 2008, 20: 803-806.

2. Babudieri B: Q fever: a zoonosis. Adv Vet Sci 1959, 5: 81-181. 
3. Meador VP, Deyoe BL, Cheville NF: Pathogenesis of Brucella abortus infection of the mammary gland and supramammary lymph node of the goat. Vet Pathol 1989, 26: 357-368.

4. Perez J, Quezada M, Lopez J, Casquet O, Sierra MA, de las Mulas JM: Immunohistochemical detection of Brucella abortus antigens in tissues from aborted bovine fetuses using a commercially available polyclonal antibody. J Vet Diagn Invest 1998, 10: 17-21.

5. Fournier PE, Marrie TJ, Raoult D: Diagnosis of Q fever. J Clin Microbiol 1998, 36: 18231834.

6. Dilbeck PM, McElwain TF: Immunohistochemical detection of Coxiella burnetii in formalinfixed placenta. J Vet Diagn Invest 1994, 6: 125-127.

7. Dag S, Büyük F, Özen H, Çelebi Ö, Karaman M, Akca D, Şahin, M: Detection of Brucella spp. in vaginal swab samples of aborting cattle: Comparison of immunoperoxidase to bacteriological culture technique. Kafkas Univ Vet Fak 2009, 18: 617-622.

8. Crowley E, Bird P, Fisher K, Goetz K, Boyle M, Benzinger MJ Jr, Juenger M, Agin J, Goins D, Johnson R: Evaluation of the VITEK 2 Gram-negative $(\mathrm{GN})$ microbial identification test card: collaborative study. J AOAC Int 2012, 95(3);778-85.

9. Cekovska Z, Petrovska M, Jankoska G, Panovski N, Kaftandzieva A: Isolation, identification and antimicrobial susceptibility of brucella blood culture isolates. Prilozi. 2010,31(1);117-132.

10. Ozkaraca M, Ceribasi S, Ceribasi AO, Kilic A, Ongor H: The role of apoptosis and autophagy in bovine abortions associated with Brucella Spp. Acta Veterinaria-Beograd 2016, 66: 37-50.

11. Ozkaraca M, Ceribasi S, Ceribasi AO, Kilic A, Altun S, Comakli S, Ongor H: Determination of Coxiella burnetii in bovine foetuses using PCR and immunohistochemistry. Veterinarni Medicina, 2016: 61(8).

12. Beytut E, Şahin NM, Erginsoy S, Sözmen M: Pathological, immunohistochemical, and bacteriological findings in the mammary glands and supramammary lymph nodes of cows with a history of abortion due to Brucella abortus. Turk J Vet Anim Sci 2009, 33(1): 37-43.

13. Emikpe BO, Yussouf SM, Ezeasor CK, Tanko PN: Immunohistochemical detection of Brucella mellitensis and Coxiella burnetii antigens in formalin-fixed tissues of West African Dwarf goats. Arch Clin Microbiol 2013, 4: doi: 10.3823/270.

14. Palmer MV, Cheville NF, Jensen AE: Experimental infection of pregnant cattle with the vaccine candidate Brucella abortus strain RB51: pathologic, bacteriologic, and serologic findings. Vet Pathol 1966, 33: 682-691.

15. Al Dahouk S, Tomaso H, Nöckler K, Neubauer H, Frangoulidis, D: Laboratory-based diagnosis of brucellosis--a review of the literature. Part II: serological tests for brucellosis. Clin Lab 2003, 49: 577-589.

16. Milli ÜH: Dişi genital sistem. In: Veteriner Patoloji. eidted by Hazıroğlu. R., Milli. Ü.H., Ankara, 2001, 477-483.

17. Gorham SL, Enright FM, Snider TG, Roberts ED: Morphologic lesions in Brucella abortus infected ovine fetuses. Vet Pathol 1986, 23: 331-332.

18. Yazıcıoglu Ö: Pathological and immunoperoxidase studies on the fetal lesions of ovine bruceliosis. Vet J Ankara Univ 1997, 44: 291-307.

19. Xavier MN, Paixão TA, Poester FP, Lage AP, Santos RL: Pathological, immunohistochemical and bacteriological study of tissues and milk of cows and fetuses experimentally infected with Brucella abortus. J Comp Pathol 2009, 140: 149-157.

20. Osburo BL, Kennedy PC: Pathologic and immunologic responses of the fetal lamb to Brucella ovis. Vet Pathol 1966, 3: 110-136. 
21. Palmer NC, Kierstead M, Key DW: Placentitis and abortion in goats and sheep in ontario caused by Coxiella burnetii. Can Vet J 1983, 24: 60-61.

22. Zeman DH, Kirkbride CA, Leslie-Steen P, Duimstra JR: Ovine abortion due to Coxiella burnetii infection. J Vet Diagn Invest 1989, 1: 178-180.

23. Sanford SE, Josephson GK, MacDonald A: Coxiella burnetii (Q fever) abortion storms in goat herds after attendance at an annual fair. Can Vet J 1994, 35: 376-378.

24. Oporto B, Barandika JF, Hurtado A, Aduriz G, Moreno B, Garcia-Perez AL: Incidence of ovine abortion by Coxiella burnetii in Northern Spain. Ann NY Acad Sci 2006, 1078: 498501.

25. Martinov SP, Neikov P, Popov GV: Experimental Q Fever in sheep. Eur J Epidemiol 1989, 5: 428-431.

26. Muskens J, Wouda W, von Bannisseht-Wijsmuller T, van Maanen C: Prevalence of Coxiella burnetii infections in aborted fetuses and stillborn calves. Vet Rec 2012, 170; 260.

\title{
DIJAGNOZA Q GROZNICE I BRUCELOZE U UZORCIMA POBAČENIH PLODOVA OVACA, MIKROBIOLOŠKIM, PATOLOŠKIM I IMUNOHISTOHEMIJSKIM METODAMA
}

\author{
YESILMEN Simten, YAMAN Turan, SAĞSÖZ Hakan, BADEMKIRAN Servet
}

Bruceloza i Q groznica su dve značajne zoonoze koje izazivaju pobačaje kod preživara, a uz to su i ekonomski značajne zarazne bolesti, izazvane gram negativnim bakterijama. Iz tih razloga, dijagnoza ovih oboljenja je od velikog značaja. U ovoj studiji, ispitani su organi poreklom od 35 pobačenih fetusa ovaca koje su bile prirodno inficirane sa Brucella melitensis i Coxiella burnetii. Pored analize makroskopskih promena, korišćene su mikrobiološke (bakteriološke), histopatološke i imunohistohemijske dijagnostičke metode. Primenom imunohistohemijske metode, Brucella melitensis je dokazana u 21, a C. burnetti, u 8 slučajeva pobačenih fetusa ovaca. Mikrobiološkim (bakteriološkim) metodama, dokazano je prisustvo Br. melitensis u 18 pobačenih fetusa. Kod ostalih fetusa, mikrobiološki nalaz je bio negativan. Antigen brucela je mogao da se dokaže intracitoplazmatski, većinom u plućnim (alveolarnim) makrofagima, u uzorcima bronhija, bronhiola, glandularnim epitelnim ćelijama koje okružuju bronhijalne limfne čvorove, u neutrofilnim granulocitima, hepatocitima i u Kupferovim ćelijama. Antigen Coxiella burnetti je uočen u alveolarnim makrofagima, bronhijama, bronhiolama i alveolama kao i u citoplazmi epitelnih ćelija limfnih čvorova oko bronhija kao i u citoplazmi hepatocita i u Kupferovim ćelijama jetre. Na osnovu poređenja imunohistohemijske i mikrobiološke dijagnostike bruceloze i Q groznice može da se zaključi da su imunohistohemijske metode pouzdanije u odnosu na mikrobiološke dijagnostiče metode. 